\title{
Advanced glycation end-products, a pathophysiological pathway in the cardiorenal syndrome
}

\author{
Suzan Willemsen · Jasper W. L. Hartog • \\ M. Rebecca Heiner-Fokkema • Dirk J. van Veldhuisen • \\ Adriaan A. Voors
}

Published online: 23 January 2011

(c) The Author(s) 2011. This article is published with open access at Springerlink.com

\begin{abstract}
The prevalence of heart failure (HF) is increasing. A distinction is made between diastolic HF (preserved left ventricular ejection fraction (LVEF)) and systolic HF (reduced LVEF). Advanced glycation end-products (AGEs) are crystallized proteins that accumulate during ageing, but are particularly increased in patients with diabetes mellitus and in patients with renal failure. Through the formation of collagen crosslinks, and by interaction with the AGE-receptor, which impairs calcium handling and increases fibrosis, AGE-accumulation has pathophysiologically been associated with the development of diastolic and renal dysfunction. Interestingly, diastolic dysfunction is a frequent finding in elderly patients, diabetic patients and in patients with renal failure. Taken together, this suggests that AGEs are related to the development and progression of diastolic HF and renal failure. In this review, the role of AGEs as a possible pathophysiological factor that link the development and progression of heart and renal failure, is discussed. Finally, the role of AGE intervention as a possible treatment in HF patients will be discussed.
\end{abstract}

Keywords Heart failure - Advanced glycation end-products · Diastolic dysfunction · Renal failure . Cardiorenal syndrome

\footnotetext{
S. Willemsen - J. W. L. Hartog - D. J. van Veldhuisen .

A. A. Voors $(\square)$

Department of Cardiology, University Medical Center

Groningen, University of Groningen, 30.001, 9700,

RB, Groningen, The Netherlands

e-mail: a.a.voors@thorax.umcg.nl

M. R. Heiner-Fokkema

Department of Laboratory Medicine,

Laboratory of metabolic disease, University Medical Center

Groningen, Groningen, The Netherlands
}

\section{Introduction}

The prevalence of chronic heart failure (HF) increases fast due to a population of increasing age and an increasing prevalence of diabetes, resulting in a prevalence of HF of $10-20 \%$ in $70-80$ year old people $[1,2]$. Chronic HF may occur in the presence of a preserved (diastolic HF) or depressed (systolic HF) left ventricular ejection fraction (LVEF), both having a similar (poor) prognosis [1, 3-5]. The prevalence of diabetes in systolic HF is estimated at $23 \%[6,7]$ and in diastolic HF at $25-33 \%$ [8-11]. A possible mechanism underlying diastolic HF may be an increase in advanced glycation end-products (AGEs). AGEs are formed during a non-enzymatic reaction between proteins and sugar residues [12,13]. AGEs accumulate in the body with age and are increased in patients with chronic systolic and diastolic HF, diabetic complications and renal dysfunction [12, 14]. In diabetic HF patients tissue AGEs are more increased compared with HF patients without diabetes [14]. Whether a difference in accumulation of AGEs in diabetic patients between systolic and diastolic HF is present, remains to be established. AGEs can also activate the receptor for AGE (RAGE) and thereby induce cardiovascular dysfunction [12]. In cardiovascular disease, renal dysfunction often exists and is frequently referred to as the cardiorenal syndrome [15]. The cardiorenal syndrome is a disorder of the heart and kidneys whereby acute or chronic dysfunction in one organ may induce acute or chronic dysfunction in the other and vice versa [16]. Interestingly, patients with renal dysfunction often have diastolic dysfunction, and have an increased prevalence of HF, in particular diastolic HF [17-20]. In addition, the risk factors for developing renal dysfunction have an overlap with the risk factors for the accumulation of AGEs. 


\section{Cardiorenal syndrome}

In patients with chronic HF the co-existence of renal dysfunction is common, and renal failure is among the strongest predictor of mortality in patients with HF [21]. This co-existence has often been referred to as "cardiorenal syndrome", in which acute or chronic dysfunction in one organ may induce acute or chronic dysfunction in the other organ $[16,22]$. The pathophysiology of the cardiorenal syndrome is multifactorial and involves decreased renal perfusion, atherosclerosis and inflammation, endothelial dysfunction and neurohormonal activation [23, 24].

\section{Advanced glycation end-products}

Advanced glycation end-products (AGEs) are a heterogeneous group of compounds, formed by oxidative and non-oxidative reactions between proteins and sugar residues, called the Maillard reaction [12, 13]. The Maillard reaction is a slow reaction and initiates when protein amino groups are exposed to sugar adducts, and proceeds from reversible Schiff base adducts to more stable, slowly reversible Amadori products (e.g. HbA1c). It further proceeds through the re-arrangement of Amadori products to the formation of stable and irreversible AGE compounds, for example $\mathrm{N}^{\varepsilon}$-(carboxymethyl)lysine (CML), $\mathrm{N}^{\varepsilon}$-(carboxyethyl)lysine (CEL), and pentosidine [12, 13]. The final step is catalyzed by oxidative stress, defined as a high steady state level of reactive oxygen species (ROS), which causes an increase in AGEs [12]. This increase in AGEs causes acceleration of oxidation, creating a vicious circle. Rapid formation of AGEs occurs via another pathway involving reactive carbonyl compounds (RCC) during oxidative stress [25]. RCCs are produced from lipids or carbohydrates reacting with ROS. AGE accumulation in vivo occurs throughout the body, including the skin, neural, vascular and renal tissue [26, 27]. Smoking cigarettes, heated, cooked or roasted food products are possible sources of increased AGE accumulation $[12,28,29]$. AGE degradation products are excreted via the kidney [25].

AGE accumulation can be measured in blood and in tissue. In blood, the preferred technique for determination of CML and CEL is stable-isotope-dilution liquid chromatography tandem mass spectrometry (LC-MS/MS) [30]. For determination of pentosidine in blood, a rapid and sensitive high-performance liquid chromatography (HPLC) method is considered the preferred technique [31]. In skin tissue, AGE accumulation can be measured at the volar side of the lower arm, more simple and noninvasively with a skin auto-fluorescence (AF) reader (AGE-reader) [32].

\section{Advanced glycation end-products in diabetes mellitus}

Accumulation of AGEs depends on both sugar concentration and the rate of protein turnover [33]. Diabetic patients have a higher sugar concentration and therefore a higher amount of AGEs compared to healthy controls. The rate of formation of Amadori products is directly proportional to the glucose concentration [33]. It has also been shown that diabetes is a risk factor for the development of a more impaired diastolic function, independent of age [34-36]. Furthermore, diabetes is not only increasing the risk of developing HF, but also accelerates its occurrence [37]. This could be partly explained by a higher amount of AGEs, which also occurs in HF patients [35]. Interestingly, diabetics also have a more impaired diastolic function compared with non-diabetics $[34,36]$. We recently provided evidence for an association between tissue AGEs and diastolic dysfunction (measured with mean E'), suggesting that AGEs might explain diastolic dysfunction in diabetic HF patients [14].

\section{The RAGE axis}

AGEs can also bind to the receptor of AGE (RAGE) and thereby induce cardiovascular dysfunction [12]. RAGE is a multi-ligand member of the immunoglobulin superfamily of cell surface molecules that is expressed in a variety of cell lines [38]. RAGE has a C-truncated secretory isoform, soluble RAGE (sRAGE) that circulates in plasma [39]. sRAGE has been proposed to have an atheroscleroticprotective function, in particular by acting as a decoy for AGE [39-41]. AGE-accumulation can cause upregulation of RAGE [42]. When AGE is interacting with RAGE, nicotinamide adenine dinucleotide phosphate (NADPH) oxidase is activated, causing activation and inflammation of NF-kappaB, which induces further inflammation and can increase AGE-accumulation, creating a vicious cycle [42].

\section{Advanced glycation end-products in heart failure; pathophysiology}

Patients with diastolic HF have decreased ventricular relaxation, abnormal active relaxation, and/or an increase in ventricular and arterial stiffness [5, 43, 44]. The degree of diastolic dysfunction is correlated with the severity of myocardial fibrosis [45]. Several other mechanisms underlying diastolic HF have been proposed [12, 46-49]. One possible mechanism could be an increase in AGEs. AGEs may induce diastolic dysfunction in the heart through three different pathways (Fig. 1). First, AGE accumulation causes excessive cross-linking, which increases rigidity, thereby 


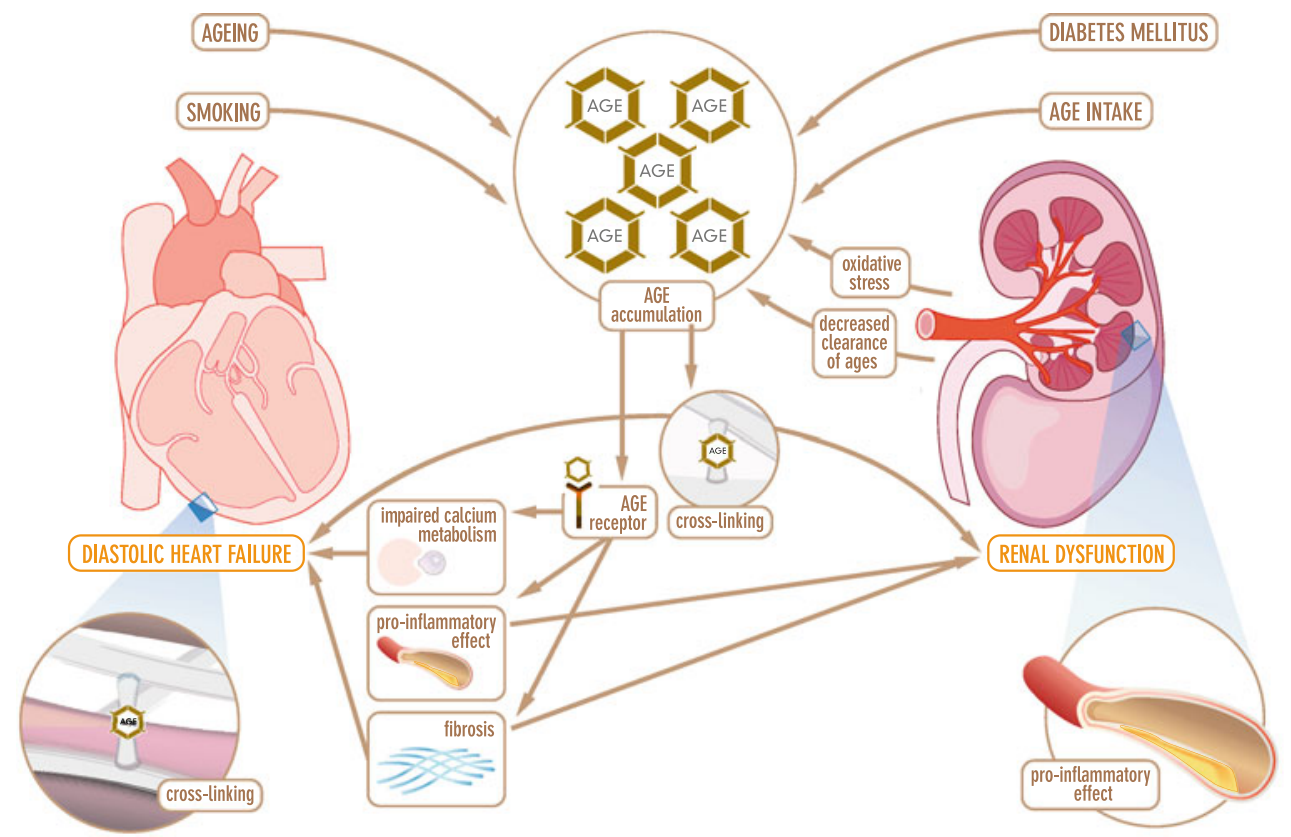

Fig. 1 Schematic representation of the pathophysiological pathways by which advanced glycation end-products causes diastolic heart failure and renal dysfunction

causing diastolic dysfunction as well as renal dysfunction. Second, when AGEs interact with the AGE receptor, the receptor is activated. Activation of AGE receptors (most important receptor is Receptor for AGE (RAGE)) causes increased fibrosis via the upregulation of transforming growth factor- $\beta$ (TGF- $\beta$ ). Third, when the AGE receptor is exposed to AGEs, it causes a significant delay in calcium reuptake. As a consequence, the duration of the repolarisation phase of the cardiac contraction may increase, subsequently causing diastolic dysfunction. Based on these data it can be hypothesized that AGEs are a causal factor in diastolic HF.

\section{Advanced glycation end-products in heart failure; evidence}

Evidence for a role of AGEs in HF patients comes from experimental work and increasing number of clinical studies. In diabetic obese rats diastolic function measured by cardiac catheterization has been shown to correlate with levels of CML [50]. AGE receptor activation influences calcium metabolism and thereby induces diastolic dysfunction. In transgenic mice that over expressed human RAGE in the heart, diastolic and systolic intracellular calcium concentration was reduced [51]. We recently showed that tissue AGEs are related to diastolic function in dialysis patients [18]. In another clinical study, we found an association between tissue AGEs and diastolic function (measured with mean E') [14].
The overall prevalence of HF is increasing. Furthermore, roughly $50 \%$ of patients die in 4 years [1]. Several factors have been established as independent predictors for survival in HF patients, among which are LVEF, New York Heart Association (NYHA) functional class, anemia and renal function [46, 52-54]. Four studies investigated the prognostic role of AGEs in HF patients. We have previously shown that plasma AGE CML was related to the severity and prognosis of 102 HF patients, but after correction for renal function this relation subsided [46]. In a second study in $141 \mathrm{HF}$ patients, pentosidine was related to severity of $\mathrm{HF}$ and it was an independent risk factor to predict adverse clinical outcome [55]. However, the authors did not adjust their findings for all known risk factors for mortality, such as hemoglobin and gender. Furthermore, they may have introduced a possible co-linearity problem by simultaneously introducing creatinine levels and estimated glomerular filtration rate (GFR) in the multivariable model. A third study showed that pentosidine was an independent predictor for cardiac events in $160 \mathrm{HF}$ patients [56]. Cardiac events were defined as a composite end point of cardiac death and rehospitalization.

\section{Advanced glycation end-products and renal failure; pathophysiology}

Several mechanisms underlying renal dysfunction have been proposed, for example decreased renal perfusion, atherosclerosis and inflammation, endothelial dysfunction 
and neurohormonal activation [24, 57-59]. Another possible mechanism could be an increase in AGEs. AGE-accumulation in patients with renal dysfunction can occur through two different pathways (Fig. 1). First, increased AGE accumulation is caused by decreased clearance of AGE degradation products. After modification or degradation in proximal tubuli, AGEs are eventually cleared in the urine [60-62]. Patients with renal dysfunction have a decreased clearance and thereby accumulation of AGEs occurs. Second, oxidative stress is enhanced in patients with renal dysfunction, which also causes an increase in AGE formation [63]. An increase in AGEs causes acceleration of oxidation, regenerating another increase in AGEs.

When endothelial cells in the kidney are stimulated by AGEs, they release the pro-inflammatory mediators vascular cell adhesion molecule-1 and intercellular adhesion molecule-1 [61, 64, 65]. This may lead to tissue damage in the kidney. In summary, it can be hypothesized that AGEs are a possible mechanism underlying renal dysfunction.

\section{Advanced glycation end-products and renal failure; evidence}

Evidence for a role of AGEs in patients with renal failure comes from experimental and clinical studies. In 50 healthy male Sprague-Dawley rats AGEs were increased by adding AGE-modified albumin. This resulted in structural changes in the glomerulus [66]. In healthy nondiabetic rats and rabbits administrating AGE-modified albumin led to an increase in vascular permeability and inflammation in the vasculature [66]. In clinical studies, AGEs accumulate during renal failure and dialysis [61, 67]. In patients with renal failure plasma AGEs are elevated [67, 68]. In patients on dialysis, tissue AGEs are even more increased compared to patients with renal failure without dialysis [69]. After renal transplantation AGE accumulation is lower than during hemodialysis, but remains elevated [69].

Renal dysfunction is strongly associated with a poor clinical outcome in HF patients [54, 70-72]. In addition, AGEs are related to the severity of $\mathrm{HF}$ and its clinical outcome as well. The prognostic role of AGEs in end-stage renal disease has however been inconsistent [73-76]. Two studies reported that high level of CML were associated with an increased mortality, but a third study showed an association with a decreased mortality. However, AGEs are a heterogenous group of compounds. Several different AGEs exist; some show cross-linking properties (pentosidine), whereas others do not (CML and CEL). All three studies only measured accumulation of the non-crosslinking AGE CML. The cross-linking AGE pentosidine was not measured. Furthermore CML was not measured with LC-MS/MS, which is the preferred technique with highest specificity. Another study reported that tissue AGE was an independent predictor of mortality and associated with cardiovascular disease in hemodialysis patients [77]. Further research is warranted to provide more insight into the prognostic role of AGEs in patients with renal dysfunction.

\section{AGEs as a pathophysiological factor in cardiorenal syndrome}

The data presented in this review suggests that AGEs may be involved as a pathophysiological factor in cardiorenal syndrome (Fig. 1 and 2). AGE-accumulation is not restricted to specific patient groups and accumulates in the body with age. With ageing, diastolic function impairs, while systolic function remains unchanged [1]. Diastolic dysfunction can be caused by AGEs through increasing rigidity and by causing a delay in calcium reuptake [12]. Patients with renal dysfunction are known to have increased AGE-accumulation and diastolic dysfunction is a frequent finding in these patients. The prevalence of diastolic dysfunction in dialysis patients varies from 25-87\% depending on definitions used and patients included [17, 20]. Diastolic dysfunction predisposes to the development of $\mathrm{HF}$, which causes a further decrease in renal function, creating a vicious circle (Fig. 1 and 2). [19]. Patients with diabetes mellitus are also known to have increased AGE-accumulation, independent of their age (Fig. 1). Accumulation of AGEs depends on both sugar concentration and the rate of protein turnover [33]. Furthermore, diabetic patients have a more impaired diastolic function compared to non-diabetics $[34,36]$. Interestingly, the risk factors for developing renal dysfunction have a certain overlap with the risk factors for the accumulation of AGEs.

Taken together, diabetic patients and patients with renal dysfunction have an increased accumulation of AGEs, and an increased prevalence of diastolic dysfunction. In addition, patients with renal dysfunction and diabetes have higher tissue AGE levels compared to patients with renal dysfunction without diabetes $[14,25]$. Whether this translates into a higher risk for new onset heart failure remains to be established. Together with its pathophysiology, where AGEs can be linked with diastolic dysfunction, we therefore suggest that increased amount of AGEs in heart and renal failure can be a common pathophysiological factor which causes both heart and renal failure (Fig. 2).

\section{Interventions}

AGE-accumulation was associated with a reduced survival in patients with diabetes, renal failure, and HF and may 
Fig. 2 Advanced glycation end-products and cardiorenal syndrome

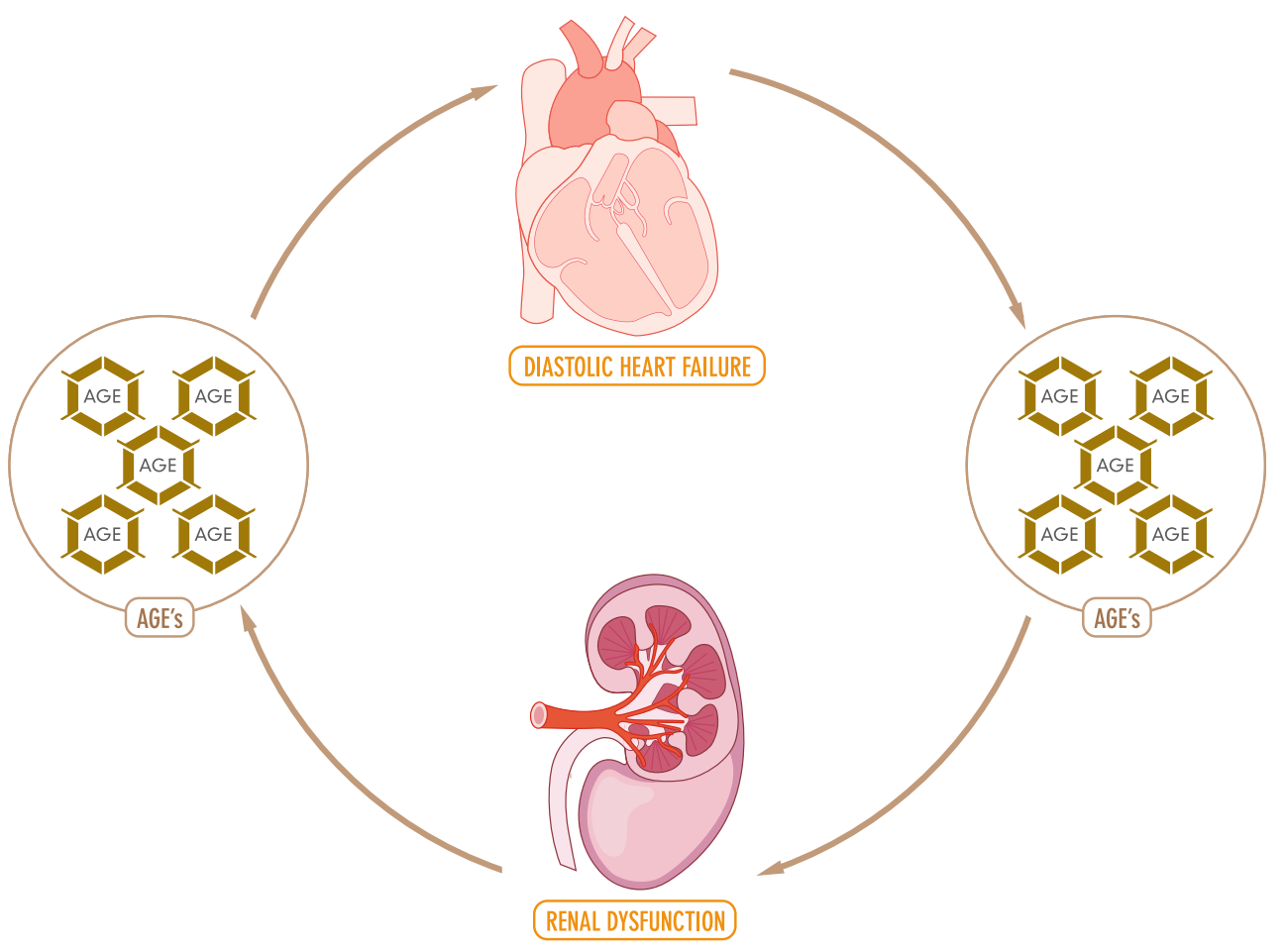

therefore be a target for intervention. The adverse effects of AGE-accumulation can be targeted in several ways.

In vitro and in vivo studies have shown that angiotensin II type 1 receptor blockers (ARBs) can reduce AGE formation [78-80]. ARBs prevent the production of reactive carbonyl and dicarbonyl compounds (RCOs), which are critical precursors of AGEs [78-81]. However, we recently showed that the angiotensin II type 1 receptor blocker eprosartan did not decrease levels of AGEs, within 6 months, in patients with hypertension and diastolic function [82].

AGE intake can also increase AGE-accumulation. Both smoking and certain food products contain high levels of AGEs and AGE precursors. Smoking cessation and lowAGE diets have been shown to reduce AGE intake and thereby AGE levels in blood [12, 28, 29].

Several AGE crosslink breakers, such as alagebrium and TRC4186, are currently under investigation for use in diabetic and non-diabetic patients. We recently conducted the BENEFICIAL study, the first prospective, randomized, double-blind, placebo controlled study to examine the effects of the AGE-breaker alagebrium on exercise capacity and cardiac function in patients with systolic HF [83].

\section{Conclusion}

There is a pathophysiological and epidemiological link between AGEs, renal dysfunction and heart failure. This suggests that AGEs are related to the development and progression of diastolic HF and renal failure. Therapies targeted at reducing the effects of AGEs will have to provide further evidence for this hypothesis.

Acknowledgments We thank C. de Meijer for illustrating our article. Dr. D.J.van Veldhuisen and Dr. A.A. Voors are clinical established investigators of the Netherlands Heart Foundation (D97-017 and 2006T37). Dr. J.W.L. Hartog is supported by a grant from the Netherlands Heart Foundation (2006T012).

Open Access This article is distributed under the terms of the Creative Commons Attribution Noncommercial License which permits any noncommercial use, distribution, and reproduction in any medium, provided the original author(s) and source are credited.

\section{References}

1. Dickstein K, Cohen-Solal A, Filippatos G, McMurray JJ, Ponikowski P, Poole-Wilson PA, Stromberg A, van Veldhuisen DJ, Atar D, Hoes AW, Keren A, Mebazaa A, Nieminen M, Priori SG, Swedberg K, Vahanian A, Camm J, De Caterina R, Dean V, Dickstein K, Filippatos G, Funck-Brentano C, Hellemans I, Kristensen SD, McGregor K, Sechtem U, Silber S, Tendera M, Widimsky P, Zamorano JL, Tendera M, Auricchio A, Bax J, Bohm M, Corra U, della Bella P, Elliott PM, Follath F, Gheorghiade M, Hasin Y, Hernborg A, Jaarsma T, Komajda M, Kornowski R, Piepoli M, Prendergast B, Tavazzi L, Vachiery JL, Verheugt FW, Zamorano JL, Zannad F (2008) ESC guidelines for the diagnosis and treatment of acute and chronic heart failure 2008: the Task Force for the diagnosis and treatment of acute and chronic heart failure 2008 of the European Society of Cardiology. Developed in collaboration with the Heart Failure Association of the ESC (HFA) and endorsed by the European Society of Intensive Care Medicine (ESICM). Eur J Heart Fail 10:933-989 
2. Fox CS, Pencina MJ, Meigs JB, Vasan RS, Levitzky YS, D'Agostino RB Sr (2006) Trends in the incidence of type 2 diabetes mellitus from the 1970s to the 1990s: the Framingham Heart Study. Circulation 113:2914-2918

3. Bhatia RS, Tu JV, Lee DS, Austin PC, Fang J, Haouzi A, Gong Y, Liu PP (2006) Outcome of heart failure with preserved ejection fraction in a population-based study. $\mathrm{N}$ Engl $\mathrm{J}$ Med 355:260-269

4. Owan TE, Hodge DO, Herges RM, Jacobsen SJ, Roger VL, Redfield MM (2006) Trends in prevalence and outcome of heart failure with preserved ejection fraction. N Engl J Med 355: 251-259

5. Zile MR, Baicu CF, Gaasch WH (2004) Diastolic heart failureabnormalities in active relaxation and passive stiffness of the left ventricle. N Engl J Med 350:1953-1959

6. Kamalesh M, Subramanian U, Sawada S, Eckert G, Temkit M, Tierney W (2006) Decreased survival in diabetic patients with heart failure due to systolic dysfunction. Eur J Heart Fail 8: 404-408

7. Shindler DM, Kostis JB, Yusuf S, Quinones MA, Pitt B, Stewart D, Pinkett T, Ghali JK, Wilson AC (1996) Diabetes mellitus, a predictor of morbidity and mortality in the studies of left ventricular dysfunction (SOLVD) trials and registry. Am J Cardiol 77:1017-1020

8. Ezekowitz JA, Lee DS, Tu JV, Newman AM, McAlister FA (2008) Comparison of one-year outcome (death and rehospitalization) in hospitalized heart failure patients with left ventricular ejection fraction $>50 \%$ versus those with ejection fraction $<50 \%$. Am J Cardiol 102:79-83

9. Fonarow GC, Stough WG, Abraham WT, Albert NM, Gheorghiade M, Greenberg BH, O'Connor CM, Sun JL, Yancy CW, Young JB (2007) Characteristics, treatments, and outcomes of patients with preserved systolic function hospitalized for heart failure: a report from the OPTIMIZE-HF Registry. J Am Coll Cardiol 50:768-777

10. Philbin EF, Weil HF, Francis CA, Marx HJ, Jenkins PL, Pearson TA, Reed RG (2000) Race-related differences among patients with left ventricular dysfunction: observations from a biracial angiographic cohort. J Card Fail 6:187-193

11. Tribouilloy C, Rusinaru D, Mahjoub H, Tartiere JM, Kesri-Tartiere L, Godard S, Peltier M (2008) Prognostic impact of diabetes mellitus in patients with heart failure and preserved ejection fraction: a prospective five-year study. Heart 94:1450-1455

12. Hartog JW, Voors AA, Bakker SJ, Smit AJ, van Veldhuisen DJ (2007) Advanced glycation end-products (AGEs) and heart failure: pathophysiology and clinical implications. Eur J Heart Fail 9:1146-1155

13. Miyata T, Sugiyama S, Saito A, Kurokawa K (2001) Reactive carbonyl compounds related uremic toxicity ("carbonyl stress"). Kidney Int Suppl 78:S25-S31

14. Willemsen S, Hartog JW, Hummel YM, van Ruijven MH, van der Horst IC, van Veldhuisen DJ, Voors AA (2011) Tissue advanced glycation end products are associated with diastolic function and aerobic exercise capacity in diabetic heart failure patients. Eur J Heart Fail 13:76-82

15. Tonelli M, Wiebe N, Culleton B, House A, Rabbat C, Fok M, McAlister F, Garg AX (2006) Chronic kidney disease and mortality risk: a systematic review. J Am Soc Nephrol 17:2034-2047

16. Ronco C, McCullough PA, Anker SD, Anand I, Aspromonte N, Bagshaw SM, Bellomo R, Berl T, Bobek I, Cruz DN, Daliento L, Davenport A, Haapio M, Hillege H, House A, Katz NM, Maisel A, Mankad S, Zanco P, Mebazaa A, Palazzuoli A, Ronco F, Shaw A, Sheinfeld G, Soni S, Vescovo G, Zamperetti N, Ponikowski P (2010) Cardiorenal syndromes: an executive summary from the consensus conference of the acute dialysis quality initiative (ADQI). Contrib Nephrol 165:54-67
17. Alpert MA (2003) Cardiac performance and morphology in endstage renal disease. Am J Med Sci 325:168-178

18. Hartog JW, Hummel YM, Voors AA, Schalkwijk CG, Miyata T, Huisman RM, Smit AJ, van Veldhuisen DJ (2008) Skin-autofluorescence, a measure of tissue advanced glycation end-products (AGEs), is related to diastolic function in dialysis patients. J Card Fail 14:596-602

19. Rakhit DJ, Zhang XH, Leano R, Armstrong KA, Isbel NM, Marwick TH (2007) Prognostic role of subclinical left ventricular abnormalities and impact of transplantation in chronic kidney disease. Am Heart J 153:656-664

20. Virga G, Stomaci B, Munaro A, Mastrosimone S, Cara M, Artuso E, Piovesana P (2006) Systolic and diastolic function in renal replacement therapy: a cross-sectional study. J Nephrol 19: $155-160$

21. Damman K, Navis G, Voors AA, Asselbergs FW, Smilde TD, Cleland JG, van Veldhuisen DJ, Hillege HL (2007) Worsening renal function and prognosis in heart failure: systematic review and meta-analysis. J Card Fail 13:599-608

22. Damman K, Navis G, Voors AA, Asselbergs FW, Smilde TD, Cleland JG, van Veldhuisen DJ, Hillege HL (2007) Worsening renal function and prognosis in heart failure: systematic review and meta-analysis. J Card Fail 13:599-608

23. Damman K, Navis G, Voors AA, Asselbergs FW, Smilde TD, Cleland JG, van Veldhuisen DJ, Hillege HL (2007) Worsening renal function and prognosis in heart failure: systematic review and meta-analysis. J Card Fail 13:599-608

24. Damman K, van Deursen VM, Navis G, Voors AA, van Veldhuisen DJ, Hillege HL (2009) Increased central venous pressure is associated with impaired renal function and mortality in a broad spectrum of patients with cardiovascular disease. J Am Coll Cardiol 53:582-588

25. Smit AJ, Gerrits EG (2010) Skin autofluorescence as a measure of advanced glycation endproduct deposition: a novel risk marker in chronic kidney disease. Curr Opin Nephrol Hypertens 19: 527-533

26. Schalkwijk CG, Baidoshvili A, Stehouwer CD, van HV, Niessen HW (2004) Increased accumulation of the glycoxidation product Nepsilon-(carboxymethyl)lysine in hearts of diabetic patients: generation and characterisation of a monoclonal anti-CML antibody. Biochim Biophys Acta 1636:82-89

27. Schleicher ED, Wagner E, Nerlich AG (1997) Increased accumulation of the glycoxidation product $\mathrm{N}$ (epsilon)-(carboxymethyl)lysine in human tissues in diabetes and aging. J Clin Invest 99:457-468

28. Cerami C, Founds H, Nicholl I, Mitsuhashi T, Giordano D, Vanpatten S, Lee A, Al Abed Y, Vlassara H, Bucala R, Cerami A (1997) Tobacco smoke is a source of toxic reactive glycation products. Proc Natl Acad Sci USA 94:13915-13920

29. Uribarri J, Peppa M, Cai W, Goldberg T, Lu M, He C, Vlassara H (2003) Restriction of dietary glycotoxins reduces excessive advanced glycation end products in renal failure patients. J Am Soc Nephrol 14:728-731

30. Teerlink T, Barto R, Ten Brink HJ, Schalkwijk CG (2004) Measurement of Nepsilon-(carboxymethyl)lysine and Nepsilon(carboxyethyl)lysine in human plasma protein by stable-isotopedilution tandem mass spectrometry. Clin Chem 50:1222-1228

31. Scheijen JL, van de Waarenburg MP, Stehouwer CD, Schalkwijk CG (2009) Measurement of pentosidine in human plasma protein by a single-column high-performance liquid chromatography method with fluorescence detection. J Chromatogr B Analyt Technol Biomed Life Sci 877:610-614

32. Meerwaldt R, Graaff R, Oomen PH, Links TP, Jager JJ, Alderson NL, Thorpe SR, Baynes JW, Gans RO, Smit AJ (2004) Simple non-invasive assessment of advanced glycation endproduct accumulation. Diabetologia 47:1324-1330 
33. Brownlee M (1995) Advanced protein glycosylation in diabetes and aging. Annu Rev Med 46:223-234

34. Loimaala A, Groundstroem K, Rinne M, Nenonen A, Huhtala H, Vuori I (2007) Exercise training does not improve myocardial diastolic tissue velocities in Type 2 diabetes. Cardiovasc Ultrasound 5:32-40

35. Smit AJ, Hartog JW, Voors AA, van Veldhuisen DJ (2008) Advanced glycation endproducts in chronic heart failure. Ann N Y Acad Sci 1126:225-230

36. Wu YW, Hsu CL, Wang SS, Tsai MW, Chu SH, Chen YS, Yang WS, Wu YT (2008) Impaired exercise capacity in diabetic patients after coronary bypass surgery: effects of diastolic and endothelial function. Cardiology 110:191-198

37. Nichols GA, Gullion CM, Koro CE, Ephross SA, Brown JB (2004) The incidence of congestive heart failure in type 2 diabetes: an update. Diabetes Care 27:1879-1884

38. Lindsey JB, Cipollone F, Abdullah SM, McGuire DK (2009) Receptor for advanced glycation end-products (RAGE) and soluble RAGE (sRAGE): cardiovascular implications. Diab Vasc Dis Res 6:7-14

39. Raposeiras-Roubin S, Rodino-Janeiro BK, Grigorian-Shamagian L, Moure-Gonzalez M, Seoane-Blanco A, Varela-Roman A, Alvarez E, Gonzalez-Juanatey JR (2010) Soluble receptor of advanced glycation end products levels are related to ischaemic aetiology and extent of coronary disease in chronic heart failure patients, independent of advanced glycation end products levels: new roles for soluble RAGE. Eur J Heart Fail 12:1092-1100

40. Lindsey JB, de Lemos JA, Cipollone F, Ayers CR, Rohatgi A, Morrow DA, Khera A, McGuire DK (2009) Association between circulating soluble receptor for advanced glycation end products and atherosclerosis: observations from the dallas heart study. Diabetes Care 32:1218-1220

41. Falcone C, Emanuele E, D'Angelo A, Buzzi MP, Belvito C, Cuccia M, Geroldi D (2005) Plasma levels of soluble receptor for advanced glycation end products and coronary artery disease in nondiabetic men. Arterioscler Thromb Vasc Biol 25:10321037

42. Ramasamy R, Yan SF, Schmidt AM. Advanced glycation endproducts: from precursors to RAGE: round and round we go. Amino Acids 2010;PMID:20957395

43. Jessup M, Brozena S (2003) Heart failure. N Engl J Med 348:2007-2018

44. Zile MR, Brutsaert DL (2002) New concepts in diastolic dysfunction and diastolic heart failure: Part I: diagnosis, prognosis, and measurements of diastolic function. Circulation 105: 1387-1393

45. Moreo A, Ambrosio G, De Chiara B, Pu M, Tran T, Mauri F, Raman SV (2009) Influence of myocardial fibrosis on left ventricular diastolic function: noninvasive assessment by cardiac magnetic resonance and echo. Circ Cardiovasc Imaging 2: 437-443

46. Hartog JW, Voors AA, Schalkwijk CG, Scheijen J, Smilde TD, Damman K, Bakker SJ, Smit AJ, van Veldhuisen DJ (2007) Clinical and prognostic value of advanced glycationend-products in chronic heart failure. Eur Heart J 28:2879-2885

47. Kass DA, Bronzwaer JG, Paulus WJ (2004) What mechanisms underlie diastolic dysfunction in heart failure? Circ Res 94: $1533-1542$

48. Zieman SJ, Kass DA (2004) Advanced glycation endproduct crosslinking in the cardiovascular system: potential therapeutic target for cardiovascular disease. Drugs 64:459-470

49. Zile MR, Brutsaert DL (2002) New concepts in diastolic dysfunction and diastolic heart failure: part II: causal mechanisms and treatment. Circulation 105:1503-1508

50. Schafer S, Huber J, Wihler C, Rutten H, Busch AE, Linz W (2006) Impaired left ventricular relaxation in type 2 diabetic rats is related to myocardial accumulation of $\mathrm{N}$ (epsilon)-(carboxymethyl) lysine. Eur J Heart Fail 8:2-6

51. Petrova R, Yamamoto Y, Muraki K, Yonekura H, Sakurai S, Watanabe T, Li H, Takeuchi M, Makita Z, Kato I, Takasawa S, Okamoto H, Imaizumi Y, Yamamoto H (2002) Advanced glycation endproduct-induced calcium handling impairment in mouse cardiac myocytes. J Mol Cell Cardiol 34:1425-1431

52. Cowburn PJ, Cleland JG, Coats AJ, Komajda M (1998) Risk stratification in chronic heart failure. Eur Heart J 19:696-710

53. Groenveld HF, Januzzi JL, Damman K, van Wijngaarden J, Hillege HL, van Veldhuisen DJ, van der Meer P (2008) Anemia and mortality in heart failure patients a systematic review and meta-analysis. J Am Coll Cardiol 52:818-827

54. Hillege HL, Nitsch D, Pfeffer MA, Swedberg K, McMurray JJ, Yusuf S, Granger CB, Michelson EL, Ostergren J, Cornel JH, de ZD, Pocock S, van Veldhuisen DJ (2006) Renal function as a predictor of outcome in a broad spectrum of patients with heart failure. Circulation 113:671-678

55. Koyama Y, Takeishi Y, Arimoto T, Niizeki T, Shishido T, Takahashi H, Nozaki N, Hirono O, Tsunoda Y, Nitobe J, Watanabe T, Kubota I (2007) High serum level of pentosidine, an advanced glycation end product (AGE), is a risk factor of patients with heart failure. J Card Fail 13:199-206

56. Koyama Y, Takeishi Y, Niizeki T, Suzuki S, Kitahara T, Sasaki T, Kubota I (2008) Soluble Receptor for advanced glycation end products (RAGE) is a prognostic factor for heart failure. J Card Fail 14:133-139

57. Ljungman S, Laragh JH, Cody RJ (1990) Role of the kidney in congestive heart failure. Relationship of cardiac index to kidney function. Drugs 39(Suppl 4):10-21

58. Stam F, van Guldener C, Schalkwijk CG, ter Wee PM, Donker AJ, Stehouwer CD (2003) Impaired renal function is associated with markers of endothelial dysfunction and increased inflammatory activity. Nephrol Dial Transplant 18:892-898

59. Zoccali C, Mallamaci F, Tripepi G (2003) Inflammation and atherosclerosis in end-stage renal disease. Blood Purif 21:29-36

60. Gugliucci A, Bendayan M (1996) Renal fate of circulating advanced glycated end products (AGE): evidence for reabsorption and catabolism of AGE-peptides by renal proximal tubular cells. Diabetologia 39:149-160

61. Hartog JW, Smit AJ, van Son WJ, Navis G, Gans RO, Wolffenbuttel BH, de Jong PE (2004) Advanced glycation end products in kidney transplant patients: a putative role in the development of chronic renal transplant dysfunction. Am J Kidney Dis 43:966-975

62. Miyata T, Ueda Y, Horie K, Nangaku M, Tanaka S, Ypersele de Strihou C, Kurokawa K (1998) Renal catabolism of advanced glycation end products: the fate of pentosidine. Kidney Int 53:416-422

63. Stenvinkel P, Alvestrand A (2002) Inflammation in end-stage renal disease: sources, consequences, and therapy. Semin Dial 15:329-337

64. Basta G, Lazzerini G, Massaro M, Simoncini T, Tanganelli P, Fu C, Kislinger T, Stern DM, Schmidt AM, De Caterina R (2002) Advanced glycation end products activate endothelium through signal- transduction receptor RAGE: a mechanism for amplification of inflammatory responses. Circulation 105:816-822

65. Rader DJ (2000) Inflammatory markers of coronary risk. N Engl J Med 343:1179-1182

66. Vlassara H, Striker LJ, Teichberg S, Fuh H, Li YM, Steffes M (1994) Advanced glycation end products induce glomerular sclerosis and albuminuria in normal rats. Proc Natl Acad Sci USA 91:11704-11708

67. Yamada K, Miyahara Y, Hamaguchi K, Nakayama M, Nakano H, Nozaki O, Miura Y, Suzuki S, Tuchida H, Mimura N (1994) Immunohistochemical study of human advanced glycosylation 
end-products (AGE) in chronic renal failure. Clin Nephrol 42:354-361

68. Zoccali C, Mallamaci F, Tripepi G (2000) AGEs and carbonyl stress: potential pathogenetic factors of long-term uraemic complications. Nephrol Dial Transplant 15(Suppl 2):7-11

69. Hartog JW, de Vries AP, Lutgers HL, Meerwaldt R, Huisman RM, van Son WJ, de Jong PE, Smit AJ (2005) Accumulation of advanced glycation end products, measured as skin autofluorescence, in renal disease. Ann N Y Acad Sci 1043:299-307

70. Al Ahmad A, Rand WM, Manjunath G, Konstam MA, Salem DN, Levey AS, Sarnak MJ (2001) Reduced kidney function and anemia as risk factors for mortality in patients with left ventricular dysfunction. J Am Coll Cardiol 38:955-962

71. Damman K, Navis G, Smilde TD, Voors AA, van der Bij W, van Veldhuisen DJ, Hillege HL (2007) Decreased cardiac output, venous congestion and the association with renal impairment in patients with cardiac dysfunction. Eur J Heart Fail 9:872-878

72. Dries DL, Exner DV, Domanski MJ, Greenberg B, Stevenson LW (2000) The prognostic implications of renal insufficiency in asymptomatic and symptomatic patients with left ventricular systolic dysfunction. J Am Coll Cardiol 35:681-689

73. Hartog JW, Gross S, Oterdoom LH, van Ree RM, de Vries AP, Smit AJ, Schouten JP, Nawroth PP, Gans RO, van Son WJ, Bierhaus A, Bakker SJ (2009) Skin-autofluorescence is an independent predictor of graft loss in renal transplant recipients. Transplantation 87:1069-1077

74. Roberts MA, Thomas MC, Fernando D, Macmillan N, Power DA, Ierino FL (2006) Low molecular weight advanced glycation end products predict mortality in asymptomatic patients receiving chronic haemodialysis. Nephrol Dial Transplant 21:1611-1617

75. Schwedler SB, Metzger T, Schinzel R, Wanner C (2002) Advanced glycation end products and mortality in hemodialysis patients. Kidney Int 62:301-310

76. Wagner Z, Molnar M, Molnar GA, Tamasko M, Laczy B, Wagner L, Csiky B, Heidland A, Nagy J, Wittmann I (2006)
Serum carboxymethyllysine predicts mortality in hemodialysis patients. Am J Kidney Dis 47:294-300

77. Meerwaldt R, Hartog JW, Graaff R, Huisman RJ, Links TP, den Hollander NC, Thorpe SR, Baynes JW, Navis G, Gans RO, Smit AJ (2005) Skin autofluorescence, a measure of cumulative metabolic stress and advanced glycation end products, predicts mortality in hemodialysis patients. J Am Soc Nephrol 16:3687-3693

78. Miyata T, van Ypersele dS (2003) Angiotensin II receptor blockers and angiotensin converting enzyme inhibitors: implication of radical scavenging and transition metal chelation in inhibition of advanced glycation end product formation. Arch Biochem Biophys 419:50-54

79. Monacelli F, Poggi A, Storace D, Durante A, Traverso N, Viviani GL, Odetti P (2006) Effects of valsartan therapy on protein glycoxidation. Metabolism 55:1619-1624

80. Saisho Y, Komiya N, Hirose H (2006) Effect of valsartan, an angiotensin II receptor blocker, on markers of oxidation and glycation in Japanese type 2 diabetic subjects: Blood pressureindependent effect of valsartan. Diabetes Res Clin Pract 74: 201-203

81. Wagenaar LJ, Voors AA, Buikema H, van Gilst WH (2002) Angiotensin receptors in the cardiovascular system. Can J Cardiol 18:1331-1339

82. Hartog JW, van de Wal RM, Schalkwijk CG, Miyata T, Jaarsma W, Plokker HW, van Wijk LM, Smit AJ, van Veldhuisen DJ, Voors AA (2010) Advanced glycation end-products, anti-hypertensive treatment and diastolic function in patients with hypertension and diastolic dysfunction. Eur J Heart Fail 12:397-403

83. Willemsen S, Hartog JW, Hummel YM, Posma JL, van Wijk LM, van Veldhuisen DJ, Voors AA (2010) Effects of alagebrium, an advanced glycation end-product breaker, in patients with chronic heart failure: study design and baseline characteristics of the BENEFICIAL trial. Eur J Heart Fail 12:294-300 